\title{
Quality of eggs after feed supplements with silkworm pupae (Bombyx mori) and black fly larvae (Hermetia illucens)
}

\author{
Mitko Lalev' ${ }^{1}$ Desislava B. Vlahova-Vangelova², Nikolay D. $\mathrm{Kolev}^{2 *}$ \\ ${ }^{1}$ Agricultural Institute, Agricultural Academy, Stara Zagora, Bulgaria \\ ${ }^{2}$ Department of Meat and Fish Technology, Technological Faculty, University of Food Technologies, Plovdiv, Bulgaria
}

\begin{abstract}
The quality of hen eggs after partial replacement (7\%) of soybean meal with silkworm pupae flour (Bombyx mori) and black soldier fly larvae flour (Hermetia illucens) was studied. Three groups of eggs were examined - C (control, standard feed), K (7\% pupae), L (7\% larvae flour). Both replacements in feed didn't have a significant effect on the $\mathrm{pH}$ of egg white and yolk $(\mathrm{p}>0.05)$. Lightness $\left(\mathrm{L}^{*}\right)$ of the egg white KW decreased, and it's a* values increased $(\mathrm{p}<0.05)$. In egg white LW, was found an opposite effect. A decrease in the yellowness $\left(b^{*}\right)$ was found in egg white $\mathrm{KW}(\mathrm{p}<0.05)$. The use of fortified feed with black soldier fly larvae significantly reduces the redness $\left(a^{*}\right)$ and yellowness $\left(b^{*}\right)$ of the colour in the yolk LY. After the addition of larvae to the feed, the $b^{*}$ value increased by about $10 \%(\mathrm{p}<0.05)$. The share of oleic (C18:1) and linoleic acid (C18:2) in the yolk (KY) increases, while the yolks of group L had the highest content of linolenic acid (C18:3). The partial replacement of soybean meal with both black soldier fly larvae and silkworm pupae increases the proportion of unsaturated fatty acids in the examined eggs.
\end{abstract}

\section{Introduction}

Eggs are a source of nutrients, fats, vitamins and minerals, but also large amounts of cholesterol [1]. In order to reduce the risk of cardiovascular disease resulting from high cholesterol intake, it is recommended to consume foods rich in polyunsaturated fatty acids (PUFA) [2]. A number of studies have demonstrated the possibility of modifying the composition of the eggs by supplementing the laying hens [3-4]. The enrichment of feed mixtures with insects is a relatively new area whose research is underway [5]. The addition of proteins and fats derived from insects, as well as live ones, to the feed used for rearing hens in the European Union is authorized from 07.09.2021 (Commision Regulation (EU) 2021/1372) [6]. Insects are an alternative source of nutrients for both humans and animals [7]. Their exoskeleton is a rich source of chitin, it in turn has a beneficial effect on the beneficial microflora in the colon. These properties could reduce the use of antibiotics in animal husbandry [5]. When it comes to insects that we can feed chickens and other slaughter animals, the yellow mealworm [8] and the Black Soldier fly larvae (Hermetia illucens) [7] are most often preferred. The high protein content and rich microelement composition make the flour from insects promising sources for improving the nutritional value of the meat of slaughter animals and eggs. The lack of sufficient scientific information and the great consumer interest form the aim of the present study - to track the changes in the physicochemical, colour characteristics and fatty acid composition of eggs, which received to feed flour from silkworm pupae (Bombyx mori) and Black Fly larvae flour (Hermetia illucens).

\section{Materials and methods}

The experiment was performed with laying hens from the starting line " $\mathrm{T}$ ", selected in the egg-laying direction, and at the start of the experiment the birds were 34 weeks old. The experiment was performed with 180 birds, divided into three groups of 60 each, respectively control group $\mathrm{C}$, experimental group $\mathrm{K}$ and experimental group L. Each group was divided into three subgroups of 20 each, housed in separate boxes ( $\mathrm{n}$ $=3$ ). The control group of laying hens $(\mathrm{C})$ received a standard feed mixture. In an experimental group of laying hens (K), soybean meal in the standard mixture was replaced with 7\% silkworm pupae (Bombyx mori). In experimental group L, the soybean meal from the standard feed mixture was replaced with $7 \%$ flour from the larvae of the Black Soldier Fly (Hermetia illucens). The three recipes for feed mixtures are aligned on the main limiting indicators - protein, energy content, lysine, methionine, calcium, digestible phosphorus (Table 1).

Standard feed mixture means: feed prepared with traditional feed components, balanced according to the biological requirements of the age-appropriate birds, breeding technology and productive direction. The experiment was conducted for a period of 90 days. For the analyses used 60 eggs per group (20 from each subgroup), collected for a period of $72 \mathrm{~h}$. Immediately

* Corresponding author: nik0zzz11@gmail.com 
after laying, the eggs were placed in refrigerated conditions $\left(0-4^{\circ} \mathrm{C}\right)$, where they were stored until the time of analysis.

Table 1. Dietary composition of the feed mixtures.

\begin{tabular}{|l|c|c|c|}
\hline & Control & Pupae & Larvae \\
\hline Proteins (\%) & 17.008 & 17.000 & 17.002 \\
\hline Fibers (\%) & 4.857 & 4.464 & 4.618 \\
\hline Lysine (\%) & 0.808 & 0.800 & 0.801 \\
\hline $\begin{array}{l}\text { Methionine } \\
\text { (\%) }\end{array}$ & 0.386 & 0.387 & 0.380 \\
\hline Calcium (\%) & 3.720 & 3.721 & 3.722 \\
\hline $\begin{array}{l}\text { Digestible } \\
\text { phosphorus (\%) }\end{array}$ & 0.383 & 0.386 & 0.386 \\
\hline $\begin{array}{l}\text { Energy value } \\
\text { (kcal/kg) }\end{array}$ & 2807.440 & 2801.060 & 2804.460 \\
\hline
\end{tabular}

\subsection{Sample preparation}

Samples for analysis were prepared by homogenizing a previously taken average sample of the respective sample and tested immediately.

\section{$2.2 \mathrm{pH}$ determination}

The $\mathrm{pH}$ value of the samples was measured electro potentiometrically [9] with a $\mathrm{pH}$ meter equipped with a temperature and combined $\mathrm{pH}$ electrode [10].

\subsection{Determination of colour characteristics}

The Konica Minolta colorimeter CR-410 (Konica Minolta Holding, Inc., Ewing, New Jersey, USA) was used to evaluate the lightness ( $\mathrm{L}^{*}$ value), the red component $\left(\mathrm{a}^{*}\right.$ value) and the yellow component $\left(\mathrm{b}^{*}\right.$ value) [11].

\subsection{Determination of water content}

The water content and dry matter of the samples were determined by a standard weight method after drying the sample to a constant weight at $105^{\circ} \mathrm{C}$ [12].

\subsection{Determination of ash content}

The total ash content of the samples was determined by mineralization of the samples by a standard AOCS method [13].

\subsection{Lipid extraction}

Extraction of total lipids from egg yolks was performed by the method of Bligh and Dyer [14], improved by Güntersperger and Escher [15].

\subsection{Determination of the fatty acid profile}

The studies on the fatty acid composition of yolk triacylglycerols [16] were performed using a GC gas chromatographic system Thermo Scientific, model Trace GC ultra with fid detector.

\section{Results and discussion}

Replacing soybean meal from mixtures with 7\% silkworm pupae flour (Bombyx mori) or 7\% Black Soldier fly larvae flour (Hermetia illucens) did not have a statistically significant effect on the $\mathrm{pH}$ and ash content of egg white and egg yolk ( $p>0.05)$ (Table 2). Previous researches also report that replacing the standard soya bean meal diet with Hermetia illucens larva meal did not affect significantly $\mathrm{pH}$ and ash content of eggs white and yolk [17-18].

Table 2. pH, dry matter, ash and water content of eggs white and yolk.

\begin{tabular}{|c|c|c|c|c|}
\hline & $\begin{array}{c}\text { Ash } \\
\text { content, \% }\end{array}$ & $\begin{array}{c}\text { Water } \\
\text { content, \% }\end{array}$ & $\begin{array}{c}\text { Dry } \\
\text { matter, \% }\end{array}$ & $\mathbf{p H}$ \\
\hline \multicolumn{5}{|c|}{ White } \\
\hline $\begin{array}{l}\text { Control } \\
(\mathrm{CW})\end{array}$ & $0.015^{\mathrm{a}} \pm 0.01$ & $37.87^{b} \pm 0.36$ & $62.17^{b} \pm 0.51$ & $8.34^{\mathrm{a}} \pm 0.15$ \\
\hline $\begin{array}{l}\text { Pupae } \\
\text { (KW) }\end{array}$ & $0.013^{\mathrm{a}} \pm 0.02$ & $34.57^{\mathrm{a}} \pm 0.48$ & $65.43^{c} \pm 0.60$ & $8.16^{\mathrm{a}} \pm 0.15$ \\
\hline $\begin{array}{l}\text { Larvae } \\
(\mathrm{LW})\end{array}$ & $0.015^{\mathrm{a}} \pm 0.02$ & $47.09^{c} \pm 0.61$ & $52.91^{\mathrm{a}} \pm 0.39$ & $8.31^{\mathrm{a}} \pm 0.11$ \\
\hline \multicolumn{5}{|c|}{ Yolk } \\
\hline $\begin{array}{l}\text { Control } \\
\text { (CY) }\end{array}$ & $0.014^{\mathrm{a}} \pm 0.03$ & $29.19^{c} \pm 0.36$ & $70.81^{\mathrm{a}} \pm 0.49$ & $6.29^{a} \pm 0.15$ \\
\hline $\begin{array}{l}\text { Pupae } \\
\text { (KY) }\end{array}$ & $0.018^{\mathrm{ab}} \pm 0.02$ & $23.56^{\mathrm{a}} \pm 0.52$ & $76.44^{\mathrm{c}} \pm 0.51$ & $6.35^{\mathrm{a}} \pm 0.18$ \\
\hline $\begin{array}{l}\text { Larvae } \\
(\mathrm{LY})\end{array}$ & $0.020^{\mathrm{b}} \pm 0.01$ & $26.67^{b} \pm 0.51$ & $73.33^{b} \pm 0.51$ & $6.18^{a} \pm 0.15$ \\
\hline
\end{tabular}

${ }^{*}$ Results are presented as Mean \pm SEM.

$\mathrm{a}, \mathrm{b}, \mathrm{c}-$ are indexing statistically significant differences $(\mathrm{p}<0.05)$ between means in each column for each sample (white or yolk).

The dry matter content is highest in the eggs of laying hens receiving as supplementation of silkworm. Compared to the controls CW, it was $5 \%(\mathrm{p}<0.05)$ and $8 \%(\mathrm{p}<0.05)$ higher in whites $(\mathrm{KW})$ and yolks $(\mathrm{KY})$, respectively. Conversely, after a $7 \%$ replacement with Black Soldier fly larvae flour (Hermetia illucens), the dry matter was $17 \%$ lower in whites LW compared to CW. As an explanation of this phenomena can be the high overall chitin content in the feed mixture. Chitin is as a polysaccharide and main component of insects' exoskeleton, has previously study negative properties against protein digestion [19-20]. The lower amount of dry matter may be affected by the lower protein digestibility of feed and potentially lower protein content in the egg albumen. The data on the water content correspond to the obtained results for dry matter (Table 1). The lowest is the water content in the egg white $(\mathrm{KW})$ and the yolk (KY), in which the highest content $(\mathrm{p}<0.05)$ of dry matter was found.

The obtained results for the ash content of the examined eggs are in correlation with the reported by 
other researchers whom fed laying quails with black soldier fly larvae [18].

The instrumentally captured colour characteristics of the eggs are presented in Table 3. The observed trends are different between the components of the color. After the $7 \%$ replacement of soybean meal with silkworm pupae flour (Bombyx mori) led to a decrease in the lightness of the colour in the egg white $(\mathrm{KW})$. In the meantime, a statistically significantly $(p<0.05)$ increase is evaluated in the samples LW.

The addition of larvae of the black soldier fly (Hermetia illucens) to the feed, resulted in more significant shade of green (-7.10) of egg white, while in the CW samples the deviation of the $\mathrm{a}^{*}$ component is to the red colour. The evaluated results may be a consequence of the contained in black soldier fly pigments [18-19].

The most intense is the yellowness $\left(b^{*}\right)$ is evaluated in the control egg white $(\mathrm{CW})$. As a comparison, a statistically significant decrease in $b^{*}$ values in both experimental egg whites KW and LW, more pronounced in $\mathrm{KW}$ was found.

The results for the colour characteristics of the egg yolk (Table 3), showed that the darkest colour was after the partial replacement of the soybean meal of the laying hens with $7 \%$ pupae of the silkworm (KY). Control yolk (CY) is characterized with highest $\mathrm{L}^{*}$ values, $2.8 \%$ higher than KY. The decrease in L* in LY (laying hens fed with black soldier fly larvae) was lower but statistically significant. Similar decrease in colour lightness was evaluated by Secci et al. [17], where the soybean meal was replaced with $H$. illucens.

The use of black soldier fly (Hermetia illucens) and pupae (Bombyx mori) in feed significantly reduces the red component of the colour in the yolk. Compared to the control (CY), the a* component decreased by $1.7 \%$ $(\mathrm{p}<0.05)$ after $7 \%$ replacement of black soldier fly larvae $(\mathrm{LY})$ and by $0.6 \%(\mathrm{p}<0.05)$ when replaced with pupae $(\mathrm{KY})$. The CY are characterized by mid-level yellowness through all samples. A $10 \%$ lower $(\mathrm{p}<0.05)$ $\mathrm{b}^{*}$ values are evaluated in KY and opposite $10 \%$ increase $(p<0.05)$ is established in LY.

Feeding laying hens with H. illucens leaded to an increase in yellowness of egg yolk [17]. Possible explanation for the changes in colour characteristics for both experimental yolks (KY and LY) maybe due to accumulation of $\gamma$-tocopherol and $\beta$-carotene, that is previously reported phenomena [17].

Due to the different fatty acid profile of both silkworm pupae (Bombyx mori) and black soldier fly larvae (Hermetia illucens) changes in fatty acid profile of egg yolk is established. A 2.93 and $4.77 \%(p>0.05)$ increase in the content of oleic (C 18:1) and linoleic acid (C 18:2), respectively in KY, compared to control. In the egg yolks from hens feed supplements with black soldier fly larvae flour (LY) is evaluated the highest content of linolenic acid (C 18:3) (Table 4).

Table 3. Colour characteristics of egg whites and yolks.

\begin{tabular}{|l|c|c|c|}
\hline & L$^{*}$ & $\mathbf{a}^{*}$ & $b^{*}$ \\
\hline \multicolumn{4}{|c|}{ White } \\
\hline $\begin{array}{l}\text { Control } \\
(\text { CW) }\end{array}$ & $63.22^{\mathrm{b}} \pm 0.10$ & $-6.76^{\mathrm{b}} \pm 0.05$ & $40.14^{\mathrm{b}} \pm 0.30$ \\
\hline $\begin{array}{l}\text { Pupae } \\
(\text { KW) }\end{array}$ & $61.04^{\mathrm{a}} \pm 0.30$ & $-6.55^{\mathrm{a}} \pm 0.06$ & $38.20^{\mathrm{a}} \pm 0.20$ \\
\hline $\begin{array}{l}\text { Larvae } \\
(\text { LW) }\end{array}$ & $64.77^{\mathrm{c}} \pm 0.10$ & $-7.10^{\mathrm{c}} \pm 0.10$ & $39.85^{\mathrm{b}} \pm 0.40$ \\
\hline \multicolumn{4}{|c|}{ Yolk } \\
\hline $\begin{array}{l}\text { Control } \\
\text { (CY) }\end{array}$ & $67.08^{\mathrm{c}} \pm 0.11$ & $4.93^{\mathrm{c}} \pm 0.05$ & $55.49^{\mathrm{b}} \pm 0.40$ \\
\hline $\begin{array}{l}\text { Pupae } \\
(\text { KY) }\end{array}$ & $65.90^{\mathrm{a}} \pm 0.10$ & $3.93^{\mathrm{b}} \pm 0.03$ & $50.31^{\mathrm{a}} \pm 0.20$ \\
\hline $\begin{array}{l}\text { Larvae } \\
(\mathbf{L Y})\end{array}$ & $66.59^{\mathrm{b}} \pm 0.20$ & $3.77^{\mathrm{a}} \pm 0.02$ & $59.24^{\mathrm{c}} \pm 0.02$ \\
\hline
\end{tabular}

*Results are presented as Mean \pm SEM.

$a, b, c-$ are indexing statistically significant differences $(p<0.05)$ between means in each column for each sample (white or yolk).

The ratio of saturated to unsaturated fatty acids is affected by both replacements in the standard feed mixtures. Both experimental yolks (KY and LY) are characterized by an increase in the content of unsaturated fatty acids, compared to the control.

Similar effect was evaluated in eggs from laying quails fed with the inclusion from 10 to $15 \%$ defatted black soldier fly larvae meal [18]. Changing the diet of laying hens with such a rich in PUFA, results in higher share of unsaturated fatty acids in the obtained eggs [4]. In an experiment with laying hens fed with flaxseed, an increase in linolenic acid (C 18:3) was reported [3]. Lui et al. [4] evaluate higher PUFA content in eggs laid by hens fed with supplementation of Hermetia illucens larvae meal. The content of arachidonic acid (C 20:0) is 1.4 and 1.6 times lower after $7 \%$ replacement of soybean meal with silkworm pupae flour (Bombyx mori) and black soldier fly larvae (Hermetia illucens), respectively. In supplemented eggs, the proportion of unsaturated fatty acids increases by about $5 \%$.

Table 4. Fatty-acid profile of egg yolks.

\begin{tabular}{|l|c|c|c|c|c|c|c|c|}
\hline & C 16:0 & C 18:0 & C 18:1 & C 18:2 & C 18:3 & C 20:0 & Saturated FA & Unsaturated FA \\
\hline Control (CY) & $27.29^{\mathrm{a}} \pm 0.31$ & $4.95^{\mathrm{a}} \pm 0.13$ & $6.97^{\mathrm{ab}} \pm 0.16$ & $42.14^{\mathrm{a}} \pm 0.35$ & N.F. & $16.85^{\mathrm{c}} \pm 0.25$ & $49.09^{\mathrm{c}} \pm 0.43$ & $49.11^{\mathrm{a}} \pm 0.39$ \\
\hline Pupae (KY) & $29.25^{\mathrm{b}} \pm 0.30$ & $5.89^{\mathrm{b}} \pm 0.13$ & $7.18^{\mathrm{b}} \pm 0.15$ & $44.25^{\mathrm{b}} \pm 0.33$ & N.F. & $11.91^{\mathrm{b}} \pm 0.18$ & $47.05^{\mathrm{b}} \pm 0.37$ & $51.43^{\mathrm{b}} \pm 0.37$ \\
\hline Larvae (LY) & $29.43^{\mathrm{b}} \pm 0.32$ & $6.40^{\mathrm{c}} \pm 0.15$ & $6.73^{\mathrm{a}} \pm 0.16$ & $42.29^{\mathrm{a}} \pm 0.40$ & $2.83 \pm 0.03$ & $10.39^{\mathrm{a}} \pm 0.18$ & $46.22^{\mathrm{a}} \pm 0.40$ & $51.85^{\mathrm{b}} \pm 0.43$ \\
\hline
\end{tabular}

*Results are presented as Mean \pm SEM.

$\mathrm{a}, \mathrm{b}, \mathrm{c}-$ are indexing statistically significant differences $(\mathrm{p}<0.05)$ between means in each column. 


\section{Conclusions}

The addition of larvae or pupae did not have a statistically significant effect on the $\mathrm{pH}$ of egg white and yolk ( $p>0.05)$. The dry matter content is highest in the eggs of laying hens receiving as a supplementation of silkworm pupae (Bombyx mori). After 7\% replacement of the meal with silkworm pupae, the lightness $\left(\mathrm{L}^{*}\right)$ of the egg white $\mathrm{K}$ decreased, and a * its value increased ( $\mathrm{p}$ $<0.05)$. The use of fortified feed with black soldier fly larvae significantly reduces the lightness $\left(\mathrm{L}^{*}\right)$, the red component $\left(\mathrm{a}^{*}\right)$ and the yellow component $\left(\mathrm{b}^{*}\right)$ of the colour in the yolk. The partial replacement $(7 \%)$ of soybean meal in laying mixtures with both black soldier fly larvae (Hermetia illucens) and silkworm pupae (Bombyx mori) increases the proportion of unsaturated fatty acids in the studied eggs. The share of oleic (C 18:1) and linoleic acid (C 18:2) in the yolk (K) increases after $7 \%$ replacement of soybean meal with silkworm pupae (Bombyx mori), while in the yolks of group $\mathrm{L}$ the highest content of linolenic acid (C 18:3). Partial (7\%) replacement of soybean meal with black soldier fly larvae (Hermetia illucens) or silkworm pupae (Bombyx mori) can be successfully used to improve egg quality.

\section{References}

1. J. P. Drouin-Chartier, S. Chen, Y. Li, A. L. Schwab, M. J. Stampfer, F. M. Sacks, B. Rosner, W. C. Willett, F. B. Hu, S. N. Bhupathiraju, BMJ. 368, 368:m513 (2020)

2. K. J. Bowen, W. S. Harris, P. M. Kris-Etherton, Curr. Treat. Options Cardiovasc. Med. 18, 1-16 (2016)

3. W. Jia, B. A. Slominski, W. Guenter, A. Humphreys, O. Jones, Poultry Sci. 87, 2005-2014 (2008)

4. X. Liu, X. Liu, Y. Yao, X. Qu, J. Chen, K. Xie, X. Wang, Q. Yi, X. Bing, C. He, It. J. Anim. Sci. 20, 256-266 (2021)

5. A. Van Huis, J. Insects Food Feed. 6, 27-44 (2020)

6. Commission Regulation (EU) 2021/1372 of 17 August 2021 amending Annex IV to Regulation (EC) No 999/2001 of the European Parliament and of the Council as regards the prohibition to feed nonruminant farmed animals, other than fur animals, with protein derived from animals, Offic. J. Eur. Union. L 295/1, 64 (2021)

7. L. Borrelli, L. Coretti, L. Dipineto, F. Bovera, F. Menna, L. Chiariotti, A. Nizza, F. Lembo, A. Fioretti, Sci. Rep. 7, 1-11 (2017)

8. L. Selaledi, C. A. Mbajiorgu, M. Mabelebele, Trop. Anim. Health Prod. 52, 7-16 (2020)

9. H. Korkeala, O. Mäki-Petäys, T. Alanko, O. Sorvettula, Meat Sci. 18, 121-132 (1986)

10. O. A. Young, J. West, A. L. Hart, F. F. H. van Otterdijk, Meat Sci. 66, 493-498 (2004).

11. M. C. Hunt, A. King, AMSA meat color measurement guidelines. (American Meat Science Association, Champaign, IL, 2012)
12. J. T. Keeton, B. S. Hafley, S. M. Eddy, C. R. Moser, B. J. McManus, T. P. Leffler, J. AOAC Int. 86, 1193 1202 (2003)

13. Official methods and recommended practices of the American Oil Chemists' Society. Champaign: AOCS. J. Am. Oil Chem. Soc. (2004)

14. E.G. Bligh, W.J. Dyer, Can. J. Biochem. Physiol. 37, 911-917, (1959)

15. B. Gunterensperger, F. E. Escher, J. Food Sci. 59, 689-692 (1994).

16. BSS EN ISO 12966-4: 2015. Animal and vegetable fats and oils - Gas chromatography of fatty acid methyl esters - Part 4: Determination by capillary gas chromatography (International Standardization Organization, Geneva, 2015)

17. G. Secci, F. Bovera, S. Nizza, N. Baronti, L. Gasco, G. Conte, A. Serra, A. Bonelli, G. Parisi, Animals. 12, 2191-2197 (2018)

18. A. Dalle Zotte, Y. Singh, J. Michiels, M. Cullere, Animals. 9, 115 (2019)

19. Z. Mwaniki, M. Neijat, E. Kiarie, Poultry Sci. 97, 2829-2835 (2018)

20. M. Cullere, G. Tasoniero, V. Giaccone, R. MiottiScapin, E. Claeys, S. De Smet, A. Dalle Zotte, Animals. 10, 1923-1930 (2016) 